$$
\text { Original articles }
$$

J. Perinat. Med.

2 (1974) 233

\section{Intravenous glucose tolerance test and its relation to a scoring system for the degree of diabetic fetopathy in new- born infants}

\section{B. Thalme, K. Edström}

Department of Pediatrics and Departments of Obstetrics and Gynecology, Karolinska sjukhuset, Stockholm/Sweden

Received September 12, 1973. Accepted December 15, 1973.
Diabetes mellitus in the pregnant woman is known to affect her offspring profoundly, and this is true for both gestational diabetes and for longstanding juvenile diabetes. The outcome of the pregnancy depends not only on the duration and the severity of the diabetic state before pregnancy [16], but also on the occurrence of complications and the degree of blood sugar control during the pregnancy [13]. The infant of the diabetic mother (IDM) often presents a well-known clinical picture at birth and in the early neonatal period with e. g. high birth weight for gestational stage, a cushingoid face and stature, hypoglycemia, hyperbilirubinemia and polycythemia [3].

Infants of healthy mothers (IHM) demonstrate a low carbohydrate tolerance during the first days of life $[1,5,9]$, which is even more pronounced in preterm, small-for-gestational-age-infants [3, 6]. IDM on the other hand have a more rapid removal of glucose from the circulation than IHM after i. v. injection of glucose suggesting a state of "hyperinsulinism" in the infant of the diabetic mother $[1,5,9]$.

In order to evaluate the degree of this "hyperinsulinism" a glucose tolerance test was performed in a group of IDM during the first 24 hours after birth. The values obtained showed wide variations, but were not significantly higher than the values of IHM. This finding might be related to the care of the mothers' diabetes during pregnancy and its effect on the fetal glucose metabolism. A clinical assessment of the combined picture of the mother's diabetic state and the appearance and behavior of the newborn infant might give the prognostic guidance that the individual glucose tolerance test could not supply.

\section{Curriculum vitae}

Bertil Thalme was born 1931. 1951-1959 studies in medicine at Karolinska institutet, Stockholm. Clinical and research work in perinatology since 1960 at the Department of Pediatrics, Karolinska sjukbuset, Stockbolm. M. D. in 1967 on the thesis "Electrolyte and acid-base balance in fetal and maternal blood" and university lecturer (docent) in

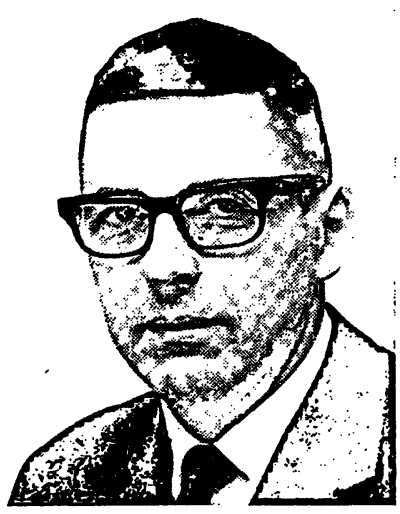
pediatrics the same year. Current studies deal with fetal and neonatal physiolog) during obstetric anesthesia.

To test this hypothesis a scoring system based on clinical and laboratory criteria was constructed retrospectively and the individual scores correlated to the infants's k-value.

\section{Material and methods}

Twenty-six infants of diabetic mothers (IDM) were subjected to an intravenous glucose tolerance test (IVGTT) at 4-24 hours age (mean age 13.4 hours). There were no signs of hyaline membrane disease in 24 of the 26 babies. The mothers, aged 18-36 years, were all insulin treated during pregnancy. Four mothers were classified as WHIrE's group $A$, four as group $B$, seven as group $C$, nine as group $D$ and two as group $F$. Nine mothers were delivered before the end of the 37th pregnancy week and seventeen at 38 to 40 weeks gestation. Eleven women were delivered vaginally and fifthteen by elective caesarean section. The mean birth weight for the IDM was $3.530 \pm 530 \mathrm{~g}$.

All IDM were delivered at the Department of Obstetrics and Gynecology and after the immediate postnatal care they were brought to the Department of Pediatrics for close observation. About one hour after birth intravenous therapy with glucose-fructose and electrolytes was started and at six hours early feeding was begun [15]. 


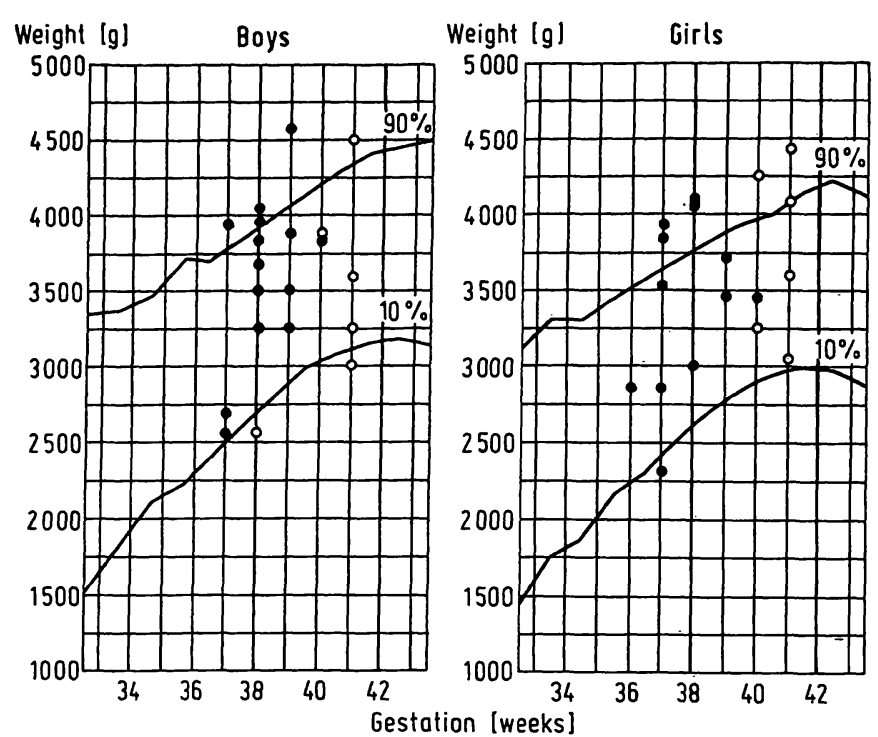

Fig. 1. Birth weights of 26 infants of diabetic mothers (IDM) (closed circles) and 12 infants of healthy mothers (open circles) plotted against their gestational age.

Twelve infants born to healthy mothers (IHM) were also subjected to an IVGTT at 4-24 hours of age (mean 15.4 hours). The mothers, aged $26-34$ years, all had uncomplicated pregnancies and normal $k$-values during the last month of pregnancy. All IHM were delivered vaginally at 38-42 weeks gestation and had a mean birth weight of $3.600 \pm 590 \mathrm{~g}$. In Fig. 1 the birth weights of all babies are plotted against corresponding gestational age. Eight IDM and four IHM were large for gestational age and one IDM and two IHM small for gestational age. The IHM were fasting at IVGTT, while the IDM were already obtaining the aforementioned glucose-fructose-infusion.

For the IVGTT $1.5 \mathrm{~g}$ glucose $/ \mathrm{kg}$ body weight was injected through a scalp vein and capillary blood samples collected by heel pricks every $10 \mathrm{~min}$ for one hour. Glucose was determined by a commercial glucose oxidase technique (KABI Reagens, Stockholm, Sweden). Absolute glucose values were used, and the $k$-value $\left(k_{t}\right)$ was calculated according to the formula: $k_{t}=\frac{0.693 \times 100}{t^{\frac{1}{2}}}$, where $t \frac{1}{2}$ is the time interval for the concentration to fall by 50 per cent. In seven IDM and nine IHM an umbilical venous catheter was introduced and blood was drawn at $0,5,10$ and $20 \mathrm{~min}$ at the IVGTT. The plasma samples were sent to the Department of Endocrinology for assay of Immunoreactive insulin by the method of HALES and RANDLE [8].

\section{Scoring criteria}

The scoring system which is summarized in Tab. I is based on both maternal and neonatal criteria related to the risk for complications in the early neonatal period. A "maternal" score and a "neonatal" score are given, the "total" score being the sum of both. Maximum maternal score is 6 points, maximum neonatal score 14 points and maximum total score 20 points.

\subsection{Maternal score}

\subsubsection{Classification}

The mother's diabetes beffore pregnancy is evaluated according to the classification of WHrTE [16]. The groups $A, B$ and $C$ including dietary regulated diabetes and insulin treated diabetes of 10-19 years' duration with no vascular disease score 1 point, while groups $D, E$ and $F$ representing insulin treated diabetes of 20 years or more duration with evidence of vascular disease score 2 points.

\subsubsection{Presence of complications}

Complications during pregnancy were classified according to their clinical severity. Thus moderate toxemia or cystitis score 1 point, while preeclampsia, polyhydramnios and severe pyelonephritis score 2 points.

\subsubsection{Adequacy of control}

Good blood sugar control was considered to have been obtained when in all 3 trimesters the blood sugar values (measured 6 times daily) were easily kept within accepted limits as given by e.g. Pedersen [13] with only one or two alterations of insulin doses. Moderately bad control (scoring 1 point) was considered to be present for neglectors, patients with more than one period of hyperglycemia requiring repeated changes in insulin dosage, or with periods of hypoglycemia. Bad control was considered present when these periods were prolonged or repeated, or if ketoacidosis was diagnosed.

\subsection{Neonatal score}

\subsubsection{Birth weight versus gestational age}

IDM are often overweight for their gestational age. Birth weights above the 90th percentile of birth weights for gestational age [4] score 1 point, while birth weights below the 90 th percentile score 0 .

\subsubsection{Diabetic fetopathy}

A baby with a plethoric, cushingoid appearance, very red skin and hypertrophy of the umbilical cord is considered typical for diabetic fetopathy and scores 2 points. 1 point is given if only one or two of these signs are present. 
Tab. I.

Scoring system

A. Matcrnal score

1. Classification

2. Presence of complications

3. Adequacy of control

B. Neonatal score

1. Birth weight versus gestational age

2. Diabctic fetopathy

3. Postnatal weight loss (\% birthweight)

4. Respiratory difficultics

5. Hyperexcitability

6. Hypoglycemia

7. Polycythemia

8. Hyperbilirubinemia

9. Congenital anomalies

\subsubsection{Postnatal weight loss}

IDM have a tendency to marked postnatal weight loss. A loss between 9 and 11 per cent of the birth weight scores 1 point and a weight loss over 11 per cent 2 points. In the scoring system we have chosen to give a maximum of 1 point to the overweight infant and a maximum of 2 points for a large postnatal weight loss.

\subsubsection{Respiratory difficulties}

The most serious complication is probably the hyaline membrane disease, a severe respiratory difficulty, which scores 2 points. The presence of moderate respiratory difficulties such as tachypnea, apneic spells, retraction of the chest and pulmonary atelectases verified by $\mathbf{x}$-ray scores only 1 point.

$\begin{array}{ll}\text { non-diabetic } & 0 \\ \text { group A-C } & 1 \\ \text { group D-F } & 2 \\ \text { none } & 0 \\ \text { moderate (sec text) } & 1 \\ \text { severe (sce text) } & 2 \\ \text { good } & 0 \\ \text { moderate (sce text) } & 1 \\ \text { bad (see text) } & 2\end{array}$

birth weight $<90$ th percentile $\quad 0$ birth weight $>90$ th percentile 1 none 0 moderate (sce text) 1 severe (see text) 2 $<9 \% \quad 0$ 9-11\% 1 $>11 \%$ none 0 moderatc 1 severe 2 none 0 moderate 1 severe 2 $\geqq 30 \mathrm{mg} / 100 \mathrm{ml}$ $20-29 \mathrm{mg} / 100 \mathrm{ml}$ $<20 \mathrm{mg} / 100 \mathrm{ml} \quad 2$ $\mathrm{Hb}<20 \mathrm{~g} / 100 \mathrm{ml}$ and/or Hct $<70 \quad 0$ $\mathrm{Hb} \geqq 20 \mathrm{~g} / 100 \mathrm{ml}$ and $\mathrm{Hct} \geqq 70 \quad 1$ $<12.0 \mathrm{mg} / 100 \mathrm{ml}$ $\geqq 12.0 \mathrm{mg} / 100 \mathrm{ml}$ none 0 present 1

\subsubsection{Hyperexcitability}

IDM have often been found to be hyperexcitable during the first days of life $[15,17]$, but only in rare cases can this be attributed to hypocalcemia or hypoglycemia. Typical symptoms are coarse waving movements of the extremities, vibrations of the hands and fine tremors of the fingers. Presence of these symptoms scores 1 point, but very pronounced symptoms with a total plasma calcium concentration below $4 \mathrm{mEq} / \mathrm{l}$ or tetanic convulsions score 2 points.

\subsubsection{Hypoglycemia, polycythemia, hyper- bilirubinemia}

The definitions suggested by CoRnBlath [3] for hypoglycemia, polycythemia and hyperbilirubinemia are used here. The criteria for the different 
scores are given in Tab. I. For hypoglycemia only low blood glucose values during the first two hours after birth were used in the scoring system. Polycythemia and hyperbilirubinemia were considered to be less definitely related to the clinical outcome than for instance hypoglycemia, and as they are also interrelated, they score only 1 point each.

\subsubsection{Congenital anomalies}

The correlation between maternal diabetes and high incidence of congenital anomalies is wellknown [13], but anomalies are difficult to grade as some of them, e. g. skeletal or renal, often are nor diagnosed until later. In the scoring system the presence of any significant anomaly, e. g. syndactylia, single umbilical artery or VOC, therefore scores 1 point.

\section{Results}

The maternal, neonatal and total scores, "resting" glucose levels, $\mathrm{k}$-values and clinical data on gestational age, mode of delivery, and birth weight are given in Tab. II. Mean values \pm 1 standard deviation are given in the text.

In IDM the mean maternal score was $2.5 \pm 1.3$, the mean neonatal score $4.0 \pm 2.1$ and the mean total score $6.5 \pm 2.6$. In IHM the corresponding values were $0,0.9 \pm 1.0$ and $0.9 \pm 1.0$ respectively.

The mean level of fasting blood sugar in IDM before IVGTT was $47.4 \pm 12.8 \mathrm{mg} / 100 \mathrm{ml}$, similar to that in IHM, $51.5 \pm 8.5 \mathrm{mg} / 100 \mathrm{ml}$.

The $\mathrm{k}$-values showed wide individual variations in both groups. The mean $\mathrm{k}_{\mathrm{t}}$ for all IDM was $1.37 \pm 0.56$ and $1.08 \pm 0.42$ for IHM. This difference was not statistically significant. The mean $\mathrm{k}_{\mathrm{t}}$ for the eight large-for-gestational-age IDM was 1.53 (range $0.87-2.23$ ) and their mean total score 8.3 (range $5-12$ ).

A mean $k_{t}=0.91$ (range $0.34-1.65$ ) was found in five IDM with a total score below 4 . $\mathrm{k}$-values above 2.0 were seen in three IDM (cases 6,12 , 15) with total scores 8,11 and 8 respectively and in one IHM (case 34). This IHM had a total score of 3, which was the highest score in the control group. Two of those three IDM and the IHM were large for gestational age. Neither the mode of delivery nor prematurity influenced the $k$ - value significantly. In the present study absolute glucose values were used for calculation of the $k$ values. $\mathrm{k}$-values determined from excess glucose values were correlated to the former $(r=0.78$; $0.001>\mathrm{p}$ ), but constantly higher with a mean difference of $0.38(0.001>\mathrm{p})$.

The plasma insulin response during IVGT'T in seven IDM and nine IHM is illustrated in Fig. 2 An exceptional high insulin response was seen in the large-for-gestational-age IHM (case 34) with the $\mathrm{k}$-value 2.10 . During the first 5 minutes a mean increase of $90.7 \pm 82.7 \mu \mathrm{U} / \mathrm{ml}$ occurred in IDM, significantly different from the mean increase of $17.2 \pm 29.2 \mu \mathrm{U} / \mathrm{ml}$ in IHM $(0.05>$ $\mathrm{p}>0.01$ ). The mean increase at 10 minutes did not differ significantly between the two groups and was $43.3 \pm 36.2 \mu \mathrm{U} / \mathrm{ml}$ in IDM and $27.5 \pm$ $56.2 \mu \mathrm{U} / \mathrm{ml}$ in IHM.

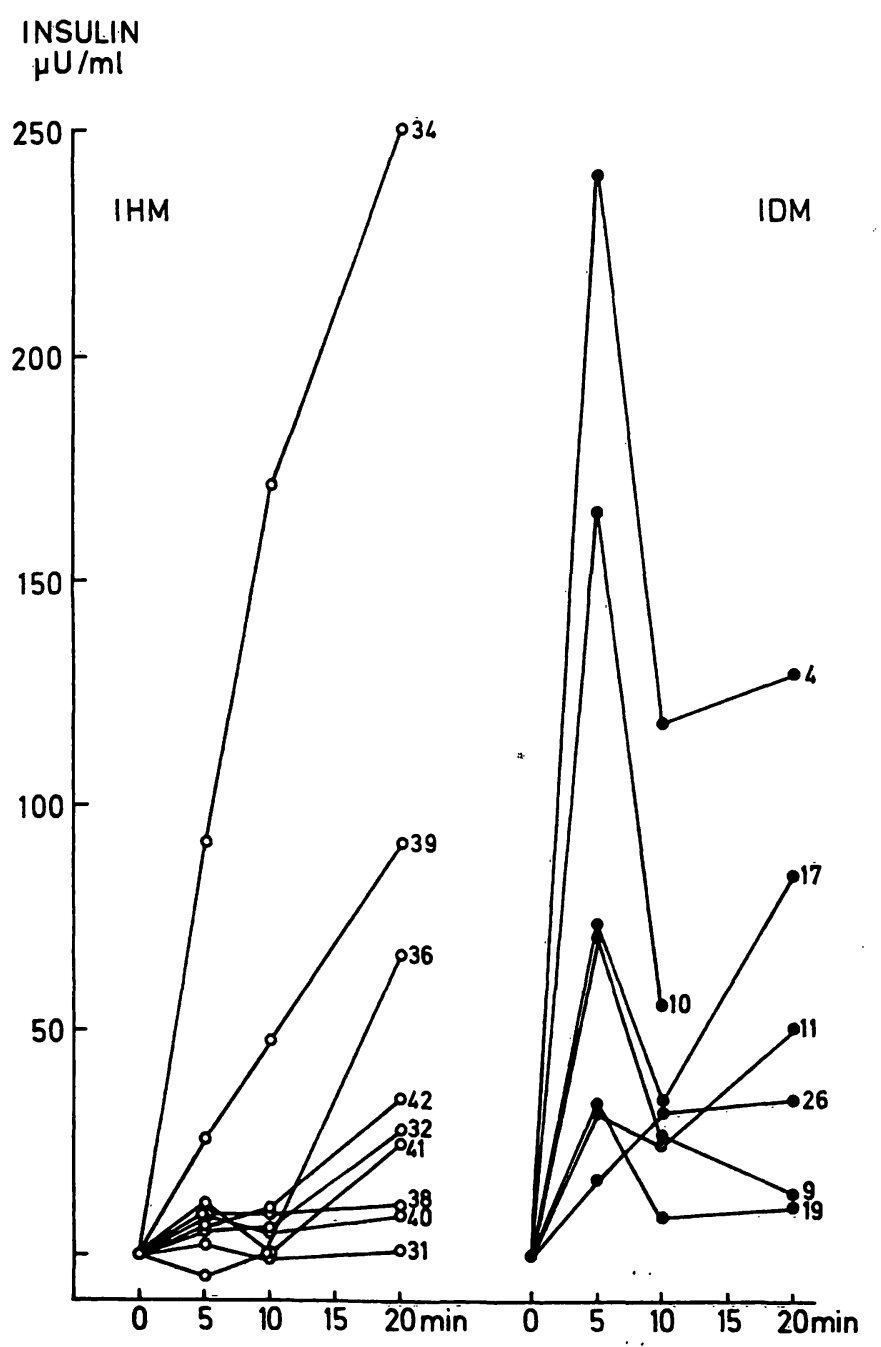

Fig. 2. Plasma insulin response in 7 infants of diabetic mothers (IDM) (closed circles) and 9 infants of healthy mothers (IHM, open circles) at IVGTT. Individual case numbers after insulin value at $20 \mathrm{~min}$. 
T'ab. II. Clinical data, scores and k-values for 26 infants of diabetic mothers (IDM) and 12 infants of healthy mothers (IHM).

\begin{tabular}{|c|c|c|c|c|c|c|c|c|c|c|c|}
\hline & \multirow{2}{*}{$\begin{array}{l}\text { Case } \\
\text { no }\end{array}$} & \multirow{2}{*}{ Sex } & \multirow{2}{*}{$\begin{array}{c}\text { Gest. } \\
\text { agc } \\
\text { (weeks) }\end{array}$} & \multirow{2}{*}{$\begin{array}{l}\text { Mode } \\
\text { of } \\
\text { delivery }\end{array}$} & \multirow{2}{*}{$\begin{array}{l}\text { Birthweight } \\
\text { (g) }\end{array}$} & \multicolumn{4}{|c|}{ Scores } & \multirow{2}{*}{$\begin{array}{c}\text { "Resting" } \\
\text { glucose } \\
\text { level }\end{array}$} & \multirow{2}{*}{$\mathrm{k}_{\mathrm{t}}$} \\
\hline & & & & & & $\begin{array}{c}\text { mater- } \\
\text { nal }\end{array}$ & $\begin{array}{l}\text { neo- } \\
\text { natal }\end{array}$ & initial & total & & \\
\hline & 1 & 우 & 36 & CS & 2.830 & 4 & 5 & 8 & 9 & 54 & 0.87 \\
\hline & $\begin{array}{l}2 \\
3 \\
4 \\
5 \\
6 \\
7 \\
8 \\
9 \\
\end{array}$ & 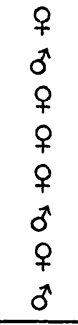 & 37 & $\begin{array}{l}\mathrm{CS} \\
\mathrm{ND}\end{array}$ & $\begin{array}{l}2.390^{2} \text { ) } \\
2.590 \\
2.860 \\
3.830^{1} \text { ) } \\
3.940^{1} \text { ) } \\
2.690 \\
3.570 \\
\left.3.910^{1}\right)\end{array}$ & $\begin{array}{l}5 \\
6 \\
2 \\
2 \\
2 \\
1 \\
4 \\
3\end{array}$ & $\begin{array}{l}4 \\
1 \\
5 \\
5 \\
6 \\
1 \\
3 \\
9\end{array}$ & $\begin{array}{r}7 \\
6 \\
6 \\
6 \\
8 \\
2 \\
6 \\
10\end{array}$ & $\begin{array}{r}9 \\
7 \\
7 \\
7 \\
8 \\
2 \\
7 \\
12\end{array}$ & $\begin{array}{l}52 \\
52 \\
29 \\
- \\
66 \\
57 \\
65 \\
30\end{array}$ & $\begin{array}{l}1.80 \\
0.82 \\
0.83 \\
1.28 \\
2.23 \\
0.86 \\
1.37 \\
1.00\end{array}$ \\
\hline IDM & $\begin{array}{l}10 \\
11 \\
12 \\
13 \\
14 \\
15 \\
16 \\
17 \\
18\end{array}$ & $\begin{array}{l}9 \\
0 \\
0 \\
0 \\
0 \\
0 \\
0 \\
+ \\
+ \\
0 \\
0\end{array}$ & 38 & $\begin{array}{l}\text { CS } \\
\text { ND }\end{array}$ & $\begin{array}{l}3.000 \\
3.480 \\
3.850 \\
3.930^{1} \text { ) } \\
4.050^{1} \text { ) } \\
4.120^{1} \text { ) } \\
4.150^{1} \text { ) } \\
3.265 \\
3.650\end{array}$ & $\begin{array}{l}2 \\
3 \\
5 \\
2 \\
1 \\
2 \\
4 \\
2 \\
2\end{array}$ & $\begin{array}{r}1 \\
4 \\
6 \\
10 \\
4 \\
6 \\
4 \\
3 \\
3\end{array}$ & $\begin{array}{l}2 \\
6 \\
8 \\
7 \\
4 \\
4 \\
8 \\
3 \\
4\end{array}$ & $\begin{array}{r}3 \\
7 \\
11 \\
12 \\
5 \\
8 \\
8 \\
5 \\
5\end{array}$ & $\begin{array}{l}45 \\
62 \\
33 \\
32 \\
27 \\
64 \\
59 \\
57 \\
23\end{array}$ & $\begin{array}{l}0.48 \\
1.16 \\
2.79 \\
1.11 \\
0.87 \\
2.10 \\
1.90 \\
1.21 \\
1.66\end{array}$ \\
\hline & $\begin{array}{l}19 \\
20 \\
21 \\
22 \\
23 \\
24\end{array}$ & $\begin{array}{l}\pi \\
0 \\
+ \\
0 \\
0 \\
+ \\
0 \\
0\end{array}$ & 39 & ND & $\begin{array}{l}3.250 \\
3.480 \\
3.480 \\
3.710 \\
3.860 \\
4.590^{1} \text { ) }\end{array}$ & $\begin{array}{l}1 \\
2 \\
2 \\
2 \\
1 \\
2\end{array}$ & $\begin{array}{l}1 \\
4 \\
3 \\
3 \\
4 \\
4\end{array}$ & $\begin{array}{l}2 \\
4 \\
3 \\
4 \\
2 \\
5\end{array}$ & $\begin{array}{l}2 \\
6 \\
5 \\
5 \\
5 \\
6\end{array}$ & $\begin{array}{l}46 \\
53 \\
39 \\
44 \\
52 \\
-\end{array}$ & $\begin{array}{l}0.34 \\
1.87 \\
1.22 \\
1.65 \\
1.69 \\
1.75\end{array}$ \\
\hline & $\begin{array}{l}25 \\
26\end{array}$ & $\begin{array}{l}\text { ㅇ } \\
\overline{0}\end{array}$ & 40 & ND & $\begin{array}{l}3.420 \\
3.820\end{array}$ & $\begin{array}{l}1 \\
2\end{array}$ & $\begin{array}{l}3 \\
2\end{array}$ & $\begin{array}{l}3 \\
4\end{array}$ & $\begin{array}{l}4 \\
4\end{array}$ & $\begin{array}{l}46 \\
52\end{array}$ & $\begin{array}{l}1.65 \\
1.20\end{array}$ \\
\hline & $\begin{array}{l}31 \\
32 \\
33 \\
34\end{array}$ & $\begin{array}{l}\pi \\
\text { 웅 } \\
0 \\
\text { क }\end{array}$ & 38 & ND & $\begin{array}{l}\left.2.560^{2}\right) \\
3.240 \\
3.860 \\
\left.4.230^{1}\right)\end{array}$ & $\begin{array}{l}0 \\
0 \\
0 \\
0\end{array}$ & $\begin{array}{l}2 \\
0 \\
1 \\
3\end{array}$ & $\begin{array}{l}2 \\
0 \\
1 \\
3\end{array}$ & $\begin{array}{l}2 \\
0 \\
1 \\
3\end{array}$ & $\begin{array}{l}30 \\
50 \\
56 \\
54\end{array}$ & $\begin{array}{l}0.77 \\
0.87 \\
0.76 \\
2.10\end{array}$ \\
\hline IHM & $\begin{array}{l}35 \\
36 \\
37 \\
38 \\
39 \\
40 \\
41 \\
42\end{array}$ & $\begin{array}{l}\pi \\
0 \\
0 \\
0 \\
0 \\
o \\
+ \\
+ \\
+ \\
0\end{array}$ & 41 & ND & $\begin{array}{l}3.000^{2} \text { ) } \\
\left.3.030^{1}\right) \\
3.230 \\
3.580 \\
3.600 \\
4.070 \\
\left.4.410^{1}\right) \\
\left.4.470^{1}\right)\end{array}$ & $\begin{array}{l}0 \\
0 \\
0 \\
0 \\
0 \\
0 \\
0 \\
0\end{array}$ & $\begin{array}{l}0 \\
0 \\
1 \\
0 \\
0 \\
1 \\
1 \\
2\end{array}$ & $\begin{array}{l}0 \\
0 \\
1 \\
0 \\
0 \\
1 \\
1 \\
2\end{array}$ & $\begin{array}{l}0 \\
0 \\
1 \\
0 \\
0 \\
1 \\
1 \\
2\end{array}$ & $\begin{array}{l}48 \\
66 \\
54 \\
48 \\
54 \\
55 \\
52\end{array}$ & $\begin{array}{l}0.82 \\
0.83 \\
1.13 \\
1.69 \\
1.05 \\
1.27 \\
0.55 \\
1.16\end{array}$ \\
\hline
\end{tabular}

The frequency of the neonatal criteria in IDM are presented in Fig. 3 and also within brackets in the text. The criteria most commonly found were diabetic fetopathy [18] and hyperexcitability [18]. Next in frequency were hypogly- cemia [9] hyperbilirubinemia [9] and overweight [8], while polycythemia [6], postnatal weight loss [5], respiratory difficulties [5] and congenital anomalies [3] were least frequent. In the control group of IHM four babies were overweight, two 


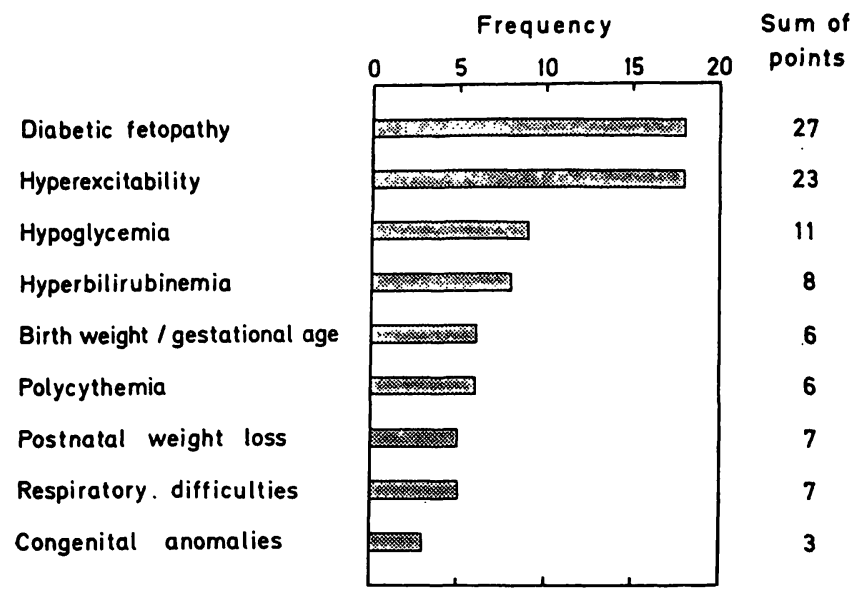

Fig. 3. Frequency and sum of scores of neonatal criteria in infants of diabetic mothers (IDM).
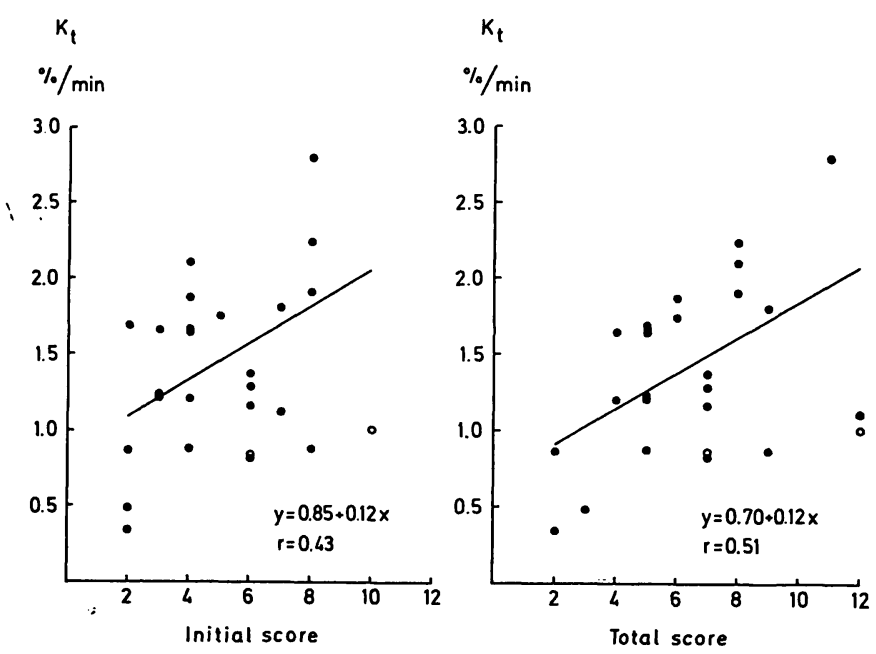

Fig. 4. The rates of glucose disappearance $\left(\mathrm{k}_{\mathrm{t}}\right)$ plotted against initial score and total score for 24 infants of diabetic mothers (IDM, closed circles). Two infants of diabetic mothers (IDM) with hyaline membrane disease are represented by open circles.

hyperexcitable and two hypoglycemic. Two IDM (cases 4 and 9) suffering from hyaline membrane disease at the time of IVGTT, were excluded from the calculation below.

No individual neonatal criterion nor the maternal score were significantly correlated to the $\mathrm{k}$-value. A significant correlation to the $k$-value was found first when the combined scores of the four most frequent neonatal criteria e. g. diabetic fetopathy, hyperexcitability, hypoglycemia and hyperbilirubinemia were added to the maternal score $(r=0.44 ; 0.05>p>0.01)$. Diabetic fetopathy, hypoglycemia, overweight, polycythemia, respiratory difficulties and congenital anomalies are possible to score during the first two hours after birth. The sum of these six scores correlates with the $\mathrm{k}$-values $(\mathrm{r}=0.41 ; 0.05>$ $p>0.01$ ), but a slightly higher correlation is obtained by adding the maternal score $(r=0.43$; $0.05>p>0.01)$. The sum of the maternal score and the score of the early neonatal criteria is called the "initial" score.

If all the nine neonatal scoring criteria were correlated with the $\mathrm{k}$-value the correlation coefficient increased further $(r=0.49 ; 0.05>$ $p>0.01)$ and the best correlation was found for the total score $(r=0.51 ; 0.05>p>0.01)$. The total score and the initial score for the IDM are plotted against their k-values in Fig. 4.

\section{Discussion}

The results from the IVGTT in both groups were in agreement with those of other authors $[5,9$, $10]$, although in the present study the k-values for IDM were somewhat lower. This can possibly be explained by the fact that our IDM had all received glucose before the IVGT'T and all except three (no 4, 14, 18) were normoglycemic at the time of the test. One of the reasons for the glucose-fructose infusion and the early feeding regime used was to prevent the occurrence of neonatal hypoglycemia. The amounts of glucose-fructose given were sufficient to prevent any sustained hypoglycemia but not enough to cause hyperglycemia.

Two IDM with low $\mathrm{k}$-values and high scores (open circles in Fig. 4), were excluded from the calculation, because the IVGTT was performed under hypoxic conditions, due to hyaline membrane disease. It is probable that the hypoxia caused an increased secretion of catecholamines, which inhibit the action and release of insulin and increase the blood glucose level by stimulating glycogenolysis and decreasing the glucose uptake. This might explain the low $\mathrm{k}$-values in these two IDM. They were treated in respirators; the baby with a total score of 7 survived and the baby with a total score of 12 died on the second day. At autopsy very small amounts of glycogen were found in muscle, heart and liver, an observation in agreement with the report of SElley [14] that infants dying of oxygen lack had minimal amounts of glycogen in their tissues.

The initial insulin response at IVGTT in the early neonatal period has been shown to be positively correlated both to birth weight and to $\mathrm{k}$-value [11] both in IDM and IHM. The birth weight in itself, even if related to gestational age, is influenced by too many irrelevant factors to be a good single discriminator of hyper- 
insulinism. The $\mathrm{k}$-value determined during the first 24 hours after birth is also influenced by factors not related to the mothers' disease as was seen e. g. in the two IDM with hyaline membrane disease. Furthermore the large individual variations decrease its value as a good determinator of the status of the newborn infant. The scoring system suggested here, utilizing clinical symptoms and laboratory data routinely noted in IDM and known to be of importance to the infants' prognosis, might be more useful for evaluation of the influence of the mothers' disease upon the infant. The high frequency of diabetic fetopathy and hyperexcitability compared to hypoglycemia and overweight in the present study might be due to an overestimation of these subjective criteria, but could also be representative for our material.

The prognostic value of the scoring system is not possible to assess fully in view of the limited number of IDM studied. There were two deaths of IDM with a total score of 8 or above, compared to none in the group with lower total scores.

\section{Summary}

The outcome of a diabetic pregnancy depends not only of the duration and the severity of the diabetic state before pregnancy, but also on the occurrence of complications and blood sugar control during pregnancy. The infant of a diabetic mother (IDM) often presents a well-known clinical picture at birth e. g. "diabetic fetopathy" and has a rapid removal of glucose from the circulation after i. v. injection of glucose ( $=$ a high $\mathrm{k}$-value). The high k-value suggests a state of "hyperinsulinism" and risk for hypoglycemia. A better prognostic guidance of the IDM might be obtained by assessment of the combined picture of the mother's diabetic state and the appearance and behavior of the IDM. To test this hypothesis a scoring system based on clinical and laboratory criteria was constructed and the individual scores correlated to the infants's $k$-value.

Twenty-six IDM and 12 IHM (= infants of healthy mothers) were subjected to an intravenous glucose tolerance test (IVGTT) at 4-24 hours age with $1.5 \mathrm{~g}$ glucose $/ \mathrm{kg}$ bw. Capillary blood was sampled every $10 \mathrm{~min}$ and the $\mathrm{k}$-value calculated according to the formula $k_{t}=\frac{0.693 \times 100}{t \frac{1}{2}}$. Plasma insulin was determined in 7 IDM and 9 IHM (Fig. 2). The mean birth weight was $3.530 \pm 530 \mathrm{~g}$ for IDM and $3.600 \pm 590 \mathrm{~g}$ for IHM (Fig. 1). All IHM and 11 IDM were delivered vaginally and 15 IDM by elective caesarean section.

The scoring system (Tab. I) was based on maternal and neonatal criteria related to the risk for complications in the
Case 9 with a total score of 12 (initial score $=10$ ) died of hyaline membrane disease on the second day. Case 1 with a total score of 8 (initial score $=8$ ), died suddenly at an age of 6 weeks; pathologic anatomic diagnosis showed bronchopneumonia. Case 13 with a total score of 12 (inital score $=7$ ) had an uneventful postnatal course, but his brother born two years earlier with a pronounced polycythemia and an initial score of 9 (total score $=9$ ) and not included in the present study due to lack of $\mathrm{k}$-value died of hyaline membrane disease on the second day. The $\mathrm{k}$-values of these three cases were much lower than those of the remaining five IDM in the group with high total score. The babies who died had also high "initial" scores. A low k-value and a total score of 7 (initial score $=6$ ) was obtained for the second IDM (case 4) with hyaline membrane disease, successfully treated in respirator. These results suggest that the combination of a high initial and total score and a low k-value might indicate a greater risk for the infant.

early neonatal period. The maternal score included: classification, complications and adequacy of control. The neonatal score comprised: overweight, diabetic fetopathy, postnatal weight loss, respiratory difficulties, hyperexcitability, hypoglycemia, polycythemia, hyperbilirubinemia and congenital anomalies.

In IDM the mean maternal score was $2.5 \pm 1.3$ and the mean neonatal score $4.0 \pm 2.1$ compared to 0 and $0.9 \pm 1.0$ in IHM (Tab. II). The mean glucose levels before IVGTT were $47.4 \pm 12.8$ in IDM and $51.5 \pm 8.5 \mathrm{mg} /$ $100 \mathrm{ml}$ in IHM. The $\mathrm{k}$-value for IDM was $1.37 \pm 0.56$ and $1.08 \pm 0.42$ for IHM and the plasma insulin response was $90.7 \pm 82.7 \mu \mathrm{U} / \mathrm{ml}$ in IDM and $17.2 \pm 29.2 \mu \mathrm{U} / \mathrm{ml}$ in IHM. Diabetic fetopathy, hypoglycemia, overweight, polycythemia, respiratory difficulties and congenital anomalies can be scored during the first two hours after birth. The sum of this score correlated with the $k$-value $(r=0.41$; $0.05>p>0.01$ ), but a higher correlation was found between the sum of the maternal and neonatal score and the $k$-valựe $(r=0.51 ; 0.05>p>0.01$, Fig. 4).

The scoring system proposed here might be useful for evaluation the influence of the mother's disease upon the infant. The prognostic value is however not possible to assess fully in view of the limited number of IDM studied. In this series there were two deaths of IDM with a total score of 8 or above. The $\mathrm{k}$-values of these cases were low suggesting that the combination of a high score and a low k-value might indicate a greater risk for the infant.

Keywords: Glucose, infants of diabetic mothers, intravenous glucose tolerance test, plasma insulin, scoring system. 


\section{Zusammenfassung}

Der intravenöse Glucose-Toleranztest und seine Beziehung zu einem Punktsystem zur Beurteilung der diabetischen Fetopathie bei Neugeborenen

Das Ergebnis einer diabetischen Schwangerschaft ist nicht nur von der Dauer und dem Schweregrad des Diabetes vor der Schwangerschaft abhängig sondern auch von dem Auftreten von Komplikationen und der Einstellung des Zuckerspiegels während der Schwangerschaft. Das Neugeborene einer diabetischen Mutter (,IDM“) bietet bei der Geburt ein wohlbekanntes klinisches Bild; biochemisch ist es dadurch auffällig, daß intravenös zugeführte Glucose rasch aus dem Kreislauf verschwindet (hoher k-Wert). Der hohe k-Wert läßt darauf schließen, daß ein Hyperinsulinismus mit dem Risiko einer Hypoglykämie besteht. Eine bessere prognostische Beurteilung des Zustandes von Neugeborenen diabetischer Mütter kann erreicht werden, wenn die diabetische Stoffwechsellage der Mutter zusammen mit dem Kohlenhydrathaushalt des Neugeborenen und seinem klinischen Bild betrachtet wird.

Um diese Hypothese zu testen, wurde ein Punktsystem, das sich auf klinische und auf labormäßig zu erfassende Kriterien stützte, entworfen und die individuellen Punktzàhlen zu den k-Werten des Neugeborenen in Beziehung gesetzt.

26 Kinder von diabetischen Müttern und 12 Kinder von gesunden Müttern wurden einem intravenösen GlucoseToleranztest im Alter von 4-24 Stunden mit 1,5 g Glucose/kg Körpergewicht unterworfen. Aus dem Kapillarblut, das alle 10 min entnommen wurde, wurde der $\mathrm{k}$-Wert nach der Formel $k_{t}=\frac{0,693 \times 100}{t \frac{1}{2}}$ errechnet. Das Plasmainsulin wurde bei 7 Kindern diabetischer Mütter und bei 9 Kindern gesunder Mütter bestimmt (Fig. 2). Das mittlere Geburtsgewicht betrug $3530 \pm 530 \mathrm{~g}$ für die Kinder diabetischer Mütter und $3600 \pm 590 \mathrm{~g}$ für die Kinder der gesunden Mütter (Fig. 1). Alle Kinder von gesunden Müttern und 11 Kinder diabetischer Mütter wurden auf vaginalem Weg geboren, 15 weitere Kinder von diabetischen Müttern durch primäre Sectio.

Das Punktsystem (Tab. I) gründet sich auf mütterliche und neonatale Kriterien, die sich auf das Risiko von Kom- plikationen in der frühen Neonatalperiode beziehen. Das mütterliche Punktsystem umfaßte: Klassifikation, Komplikationen und die adäquate Eihstellung des Diabetes. Das Punktsystem des Neugeborenen umfaßte: Úbergewicht, diabetische Fetopathie, postnataler Gewichtsverlust, Atemstörungen, UUbererregbarkeit, Hypoglykämie, Polycytämie, Hyperbilirubinämie und angeborene Anomalien.

Bei den Kindern diabetischer Mütter war der Mittelwert des mütterlichen Punktstatus 2,5 \pm 1,3 und der Mittelwert des Neugeborenenpunktstatus $4,0 \pm 2,1$ verglichen mit 0 und $0,9 \pm 1,0$ bei Kindern von gesunden Müttern (Tab. II). Der mittlere Glucosespiegel beim Glucose-Toleranztest betrug $47,4 \pm 12,8$ bei Kindern diabetischer Mütter und $51,5 \pm 8,5 \mathrm{mg} / 100 \mathrm{ml}$ bei Kindern von gesunden Müttern. Der $\mathbf{k}$-Wert für Kinder diabetischer Mütter betrug 1,37 $\pm 0,56$ bzw. 1,08 $\pm 0,42$ für Kinder von gesunden Müttern. Die Plasmainsulinspiegel betrugen $90,7 \pm 82,7 \mu \mathrm{U} / \mathrm{ml}$ bzw. $17,2 \pm$ $29,2 \mu \mathrm{U} / \mathrm{ml}$.

Die diabetische Fetopathie, die Hypoglykämie, das Übergewicht, die Polycytämie, Atemstörungen und angeborene Anomalien werden während der ersten zwei Lebensstunden bewertet. Die Summe der auf diese Weise ermittelten Punktzahlen werden mit dem $k$-Wert korreliert $(r=0,41$; $0,05>\mathrm{p}>0,01$ ); es wurde jedoch eine höhere Korrelation zwischen der Summe der mütterlichen und neonatalen Punktzahlen und dem $k$-Wert ermittelt $(r=0,51$; $0,05>p>0,01$, Fig. 4).

Das Punktsystem, das wir hier vorgeschlagen haben, kann wertvoll für die Bewertung des Einflusses der mütterlichen Erkrankung auf das Kind sein. Der prognostische Wert kann jedoch nicht vollständig beurteilt werden wegen der begrenzten Zahl von Kiñdern diabetischer Mütter, die hier untersucht wurden.

In dieser Untersuchungsreihe ereigneten sich 2 Todesfälle von Kindern diabetischer Mütter mit einem Punktstatus von 8 oder höher. Die k-Werte dieser Fälle waren niedrig und lassen vermuten, daß die Kombination einer hohen Punktzahl mit einem niedrigen $k$-Wert ein größeres Risiko für das Neugeborene anzengt.

Schlüsselworte: Glucose, intravenöser Glucose-Toleranztest, Kinder diabetischer Mütter, Plasmainsulin, Punktsystem.

\section{Résumé}

Relations entre hyperglycémie provoquée et un «score» d'evaluation des foetopathies diabétiques chez le nouveau-né

L'aboutissement de la grossesse chez la diabétique ne dépend pas seulement de la durée et de la gravité du diabète avant la grossesse, mais aussi de la fréquence des complications et des contrôles de la glycémie au cours de la grossesse. L'enfant né de mère diabétique (IDM) présente souvent un aspect clinique bien connu à la naissance: c'est la foetopathie diabétique, qui entre autres est caractérisée par la chute rapide de la glycémie après injection intra-veineuse de glucose (= valeur élevée de $\mathrm{k}$ ). Cette valeur élevée de k suggère l'existence d'un hyperinsulinisme et donc d'une tendance à l'hypoglycémie.

Une meilleure valeur pronostique de l'évolution de l'enfant né de mère diabétique (IDM) peut être obtenue par l'évaluation simultanée du diabète maternel et de l'état du nouveau-né. Pour tester cette hypothèse, les auteurs ont établi un score basé sur des critères cliniques et paracliniques; ces scores ont ensuite été confrontés individuellement avec la valeur $\mathrm{k}$ de chaque enfant.

Vingt six enfants nés de mères diabẻtiques (IDM), et douze nés de mères bien portantes (IHM) ont été soumis à une hyperglycémie provoquée par voie intra- 
veineuse (IVGTT) d 4 et 24 heures de vie, avec une dose de 1,5 $\mathrm{g}$ de glucose par $\mathrm{Kg}$.

On prélevait alors du sang capillaire toutes les $20 \mathrm{~min}$. La valcur de $\mathrm{k}$ fut calculće suivant la formule:

$$
\mathrm{k}_{\mathrm{t}}=\frac{0.693 \times 100}{\mathrm{t} \frac{1}{2}}
$$

Le taux d'insuline plasmatique fut mesuré chez 7 IDM et 9 IHM (Fig. 2). Le poids moyen à la naissance fut de $3530 \pm 530 \mathrm{~g}$ chez les $\mathrm{IDM}$, et de $3600 \pm 590 \mathrm{~g}$ chez les IHM (Fig. 1).

Tous les IHM et 11 IDM naquirent par voie basse tandis que 15 IDM furent mis au monde par césarienne élective.

Le score (Tab. I) était établi à partir de critères maternels et néonatals en corrélation avec le risque de la survenue de complications au cours de la période néonatale précoce.

L.e score maternel comportait: classification du diabète, complications, régularité des examens de contrôle.

Le score néonatal considérait: l'excès de poids, l'existence d'une foetopathie diabétique, l'existence d'une importante perte de poids après la naissance, la survenue de troubles respiratoires, la découverte d'une hyperexcitabilité, l'existence d'une hypoglycémie, d'une polycythémie ou d'une hyperbilirubinémie, la présence de malformations congénitales.

Chez les IDM, le score maternel moyen fut $2,5 \pm 1,3$, et le score foetal moyen $4 \pm 2,1$, contre respectivement 0 et $0,9 \pm 1$ chez les IHM (Tab. II).
Les valeurs moyennes de glycémie furent $47,4 \pm 12,8$ chez les IDM et $51,5 \pm 8,5 \mathrm{mg} / 100 \mathrm{ml}$ chez les IHM.

Les valeurs de $k$ furent respectivement $1,37 \pm 0,56 \mathrm{chez}$. les enfants nés de mères diabétiques (IDM), et de $1,08 \pm 0,42$ chez les enfants nés de mères bien portantes (IHM).

Les valeurs d'insulinémie plasmatique furent de $90,7 \pm$ $82,7 \mu \mathrm{U} / \mathrm{ml}$ chez les IDM, contre $17,2 \pm 29,2 \mu \mathrm{U} / \mathrm{ml}$ chez les IHM.

L'existence d'une foetopathic diabétique, l'hypoglycémie, le poids excessif, la polycythémie, les troubles respiratoires ct les malformations congénitales peuvent être évaluées, et le score établi au cours des 2 premières heures de la vie; le score établi par l'addition des différents critères, présente une corrélation significative avec la valeur de $\mathrm{k}(\mathrm{r}=0,41$; $0,05>\mathrm{p}>0,01)$. Toutefois une meilleure corrélation fut obtenue entre la somme des scores maternel et foetal, et la valeur de $k(r=0,51 ; 0,05>p>0,01$, Fig. 4).

Le score proposé dans cet article peut être très utile pour évaluer le retentissement de la maladie maternelle sur l'enfant. Il n'est cependant pas encore possible de lui attribuer une valeur pronostique certaine, compte tenu du petit nombre d'enfants nés de mères diabétiques étudiés par les auteurs.

Dans la série étudiée, les auteurs observèrent deux morts chez des IDM ayant présenté un score égal ou supérieur à 8 . Les faibles valeurs de $k$ chez ces deux enfants suggèrent le caractère particulièrement péjoratif de l'association score élevé - faible valeur de $\mathbf{k}$.

Mots-clés: Enfants nés de mères diabétiques, glucose, hyperglycémie provoquée par voie intraveineuse, score, insuline plasmatique.

\section{Bibliography}

[1] BAIRD, J. D., J. W. FARQuhar: Insulin secreting capacity in newborn infants of normal and diabetic women. Lancet 1 (1962) 71

[2] Cornblath, M., S. H. Wybregt, G. S. Baens: Carbohydrate metabolism in the newborn infant VII: Tests of carbohydrate tolerance in premature infants. Pediatrics 32 (1963) 1007

[3] Cornblath, M.: Infants born to diabetic women. Curr. Pediatr. Ther. V. Ed. Gellis, S., B. Kagan, W. B. Saunders, Philadelphia 1971

[4] Engström, L., G. Sterky: Distribution curves for length and weight in newborn infants. Läkartidningen 63 (1966) 4922

[5] v. Euler, U., Y. Larsson, B. Persson: Glucose tolerance in the neonatal period and during the first 6 months of life. Arch. Dis. Childh. 39 (1964) 393

[6] Gentz, J., B. Persson, R. Zetterström: On the diagnosis of symptomatic neonatal hypoglycaemia. Acta. Paediat. scand. 58 (1969) 449

[7] Gentz, J., R. Warrner, B. Persson, M. Cornblath: Intravenous glucose tolerance, plasma insulin, FFA and HBA in underweight newborns. Acta. paediat. scand. 58 (1969) 481
[8] Hales, C. N., P. J. Randle: Immunoassay of insulin with insulin-antibody precipitate. Biochem. J. 88 (1963) 137

[9] Isles, T. E., M. Dickson, J. W. Farquhar: Glucose tolerance and plasma insulin in newborn infants of normal and diabetic mothers. Pediatr. Res. 2 (1969) 198

[10] Mölstedt-Pedersen, L.: Aspects of carbohydrate metabolism in newborn infants of diabetic mothers. I: Intravenous glucose tolerance tests. Acta Endocrinol. 69 (1972) 174

11] Mölstedt-Pedersen, L., K. R. Jörgensen: Aspects of carbohydrate metabolism in newborn infants of diabetic mothers. III: Plasma insulin during intravenous glucose tolerance test. Acta Endocrinol. 71 (1972) 115

[12] Mölstedt-Pedersen, L., L. Wagner, J. G. Klebe: Aspects of carbohydrate-metabolism in infants of diabetic mothers. V: Plasma glucose during 150 minutes after an active intravenous glucose load. Acta Endocrinol. 71 (1972) 346

[13] Pedersen, J.: The pregnant diabetic and her newborn. Scand. University Books, Munksgaard, Copenhagen 


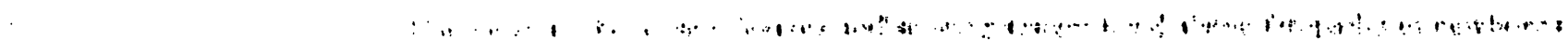

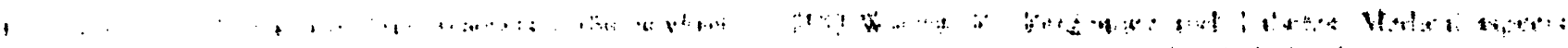
$1 . \quad \vdots \quad \therefore \quad \cdots$

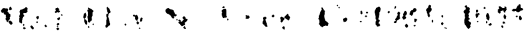

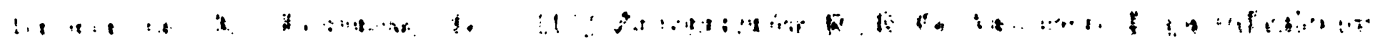

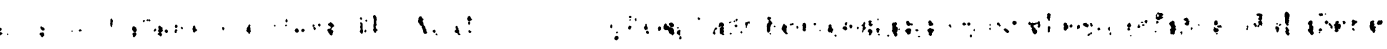

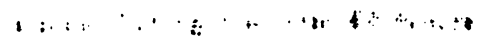
a

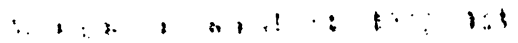

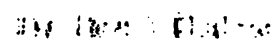

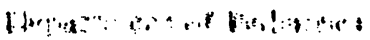

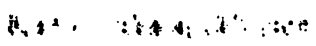

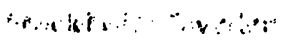

